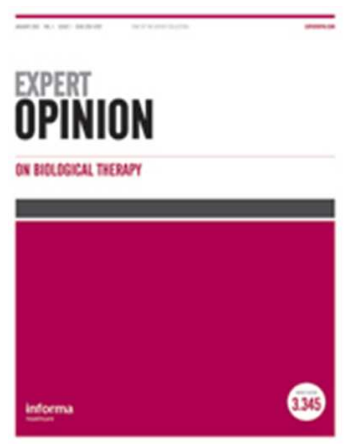

Please download and read the instructions before proceeding to the peer review

\title{
An overview of antimicrobial peptides and the latest advances in their development
}

\begin{tabular}{|r|l|}
\hline Journal: & Expert Opinion On Biological Therapy \\
\hline Manuscript ID & EOBT-2016-0221.R1 \\
\hline Manuscript Type: & Review \\
\hline Keywords: & $\begin{array}{l}\text { antimicrobial peptides, resistance, cationic peptides, antimicrobial agents, } \\
\text { defensins }\end{array}$ \\
\hline
\end{tabular}

SCHOLARONE ${ }^{\mathrm{m}}$

Manuscripts 


\section{ABSTRACT}

Introduction: The recent dramatic increase in the incidence of antimicrobial resistance has been recognized by organizations such as the United Nations and World Health Organization as well as the governments of the USA and several European countries. A relatively new weapon in the fight against severe infections caused by multi-drug resistant bacteria is antimicrobial peptides (AMPs). These include colistin, currently regarded as the last line of antimicrobial therapy against multi-drug resistant microorganisms.

Areas covered: Here we provide an overview of current research on AMPs. The focus is AMPs currently being developed for the treatment of recalcitrant bacterial infections, the synergies of AMPs and antibiotics, and the activity of AMPs against biofilm. This review also includes a brief introduction to research in the use of AMPs in infections by Mycobacterium, fungi, and parasites.

Expert opinion: In research into new antimicrobials, AMPs are gaining increasing attention. While many are natural, produced by a wide variety of organisms, others are being newly designed and chemically synthesized in the laboratory to achieve novel antimicrobial agents. The same strategy to fight infections in nature is thus being effectively exploited to safeguard human and animal health. 


\section{INTRODUCTION}

Since the introduction of sulfonamides and the discovery of penicillin in 1928, the arsenal of drugs to treat infections has greatly expanded [1]. In fact, antibiotics have become the most commonly prescribed drugs and have greatly contributed to reducing mortality and morbidity due to infectious diseases. The "golden age of antibacterials" describes the period between the 1940s and 1960s, when the vast majority of antibiotics currently in use were discovered [2]. Unfortunately, the utility of these drugs has been seriously compromised by the subsequent emergence of resistant bacteria (Table 1). The mechanisms underlying resistance are both genetic and environmental. For example, bacteria can specifically limit or reduce the permeability of their cell envelope to a given antibiotic and thus become resistant. In the case of Pseudomonas aeruginosa, it can acquire resistance to imipenem by losing expression of the porin OprD, the transporter for this antibiotic, either by mutation or disruption of the respective gene [3]. Alternatively, the bacterium may acquire the ability to degrade the antimicrobial, such as by. ß-lactamase production. This latter mechanism is of particular concern because the emergence of expanded spectrum ß-lactamases (ESBLs) has led to the emergence of new, non-responsive bacterial clones [4]. Resistance can also arise by the loss of chemical affinity between an antimicrobial and its target, as has commonly occurred in the case of streptococci; this mechanism was also the main cause of penicillin resistance in meningococci [5,6]. The wide variety of efflux systems able to pump out antimicrobials from the bacterial cell is another worrisome mechanism of resistance because most of the pumps are highly unspecific [7]. It is also now appreciated that bacteria residing in biofilms have a much lower antimicrobial susceptibility than their planktonic or microcolonial counterparts [8].

The emergence of resistance is well illustrated by methicillin, discovered in 1959 and subsequently introduced to treat penicillin-resistant Staphylococcus aureus. However, 2 years later, methicillin-resistant phenotypes strains were isolated, first in the United Kingdom and then in Japan, Australia, and elsewhere [9]. Similarly, the aminoglycoside streptomycin, which inhibits bacterial protein synthesis was introduced for the treatment of tuberculosis, but the emergence of rRNA mutations conferring streptomycinresistance to Mycobacterium tuberculosis strains was soon reported [10].

$\sim 2 \sim$ 
The story has been the same for nearly every antibiotic, with the most recent example being lipopeptides, introduced at the beginning of this century. Strains resistant to at least one of them (daptomycin) are already known [11].

\subsection{Antimicrobial resistance today}

The US Center for Disease Control and Prevention (CDC) reported in 2013 that in 2 million people in the USA had suffered an infection caused by a resistant pathogen, and at least 23,000 of these individuals had died due to the infection. By about 2050, it is predicted that 10,000,000 deaths will be attributable to multi-resistant bacteria [12]. The Infectious Disease Society of America (IDSA) highlighted Enterococcus faecium, $S$. aureus, Klebsiella pneumoniae, Acinetobacter baumannii, P. aeruginosa, and Enterobacter (ESKAPE) as species capable of "escaping" the antibacterial action of antibiotics, including by the above-mentioned mechanisms. These species constitute a new paradigm in virulence, transmission, and antimicrobial resistance[13]. In 2014, the European Center for Disease Control published a report on antimicrobial resistance in Europe [14] that also focused on the ESKAPE pathogens. Increased levels of resistance, especially in southern European countries, was reported.

The development and spread of antibiotic-resistant bacteria are, at least in part, the result of the use, misuse, and abuse of antimicrobial agents in human and veterinary medicine as well as the food industry. In fact more than half of the antibiotics prescribed are not needed or are incorrectly used. Particularly troublesome is the widespread use of antibiotics (in many cases illegally) in livestock to promote animal growth and in aquaculture to prevent the contamination of fish stocks. Antibiotics are also prescribed indiscriminately in both humans and household pets. They have also been used as additives in cleaning products[15].

\subsection{Antimicrobial peptides.}

Antimicrobial peptides both natural and synthetic are one of the main options to overcome resistance. Moreover, some peptides, particularly those that are similar to animal defense AMPs, have immunomodulatory activity [16].

With the current dilemma of widespread resistance, including extremely resistant organisms, but a lack of availability of new antimicrobial agents, attempts are being made to "revive" older antimicrobials to treat serious infections. This is the case of

$$
\sim 3 \sim
$$


colistin (polymyxin E), a natural AMP whose use was abandoned due its toxicity [17]. However, colistin is the last option to treat infections caused by multi-drug resistant bacteria, including those caused by Pseudomonas aeruginosa and/or A. baumannii. Instead, new AMPs are in the drug discovery and development pipeline.

\section{MECHANISMS OF AMP ACTION AND RESISTANCE}

\subsection{Mechanism of action}

Although membrane permeabilization is the main mechanism of action of AMPs against pathogens, additional mechanisms have been described, including membrane destabilization, inhibition of macromolecular synthesis, intracellular translocation of the peptide, and inhibition of DNA/RNA/protein synthesis [18]. The application of "omics" to the study of resistance mechanisms has enabled explorations of transcript profiles and the role of individual genes in response to AMP challenge. For example, the AMPs pleurocidin, magainin, D-LAK120-AP13, and buforin II induce changes in alanine, aspartate, and glutamate metabolism and in the expression of $\operatorname{glt} X$, $\operatorname{dap} A$, and metB, encoding, respectively, glutamyl-tRNA synthetase, dihydropicolinate synthase, and cystathionine gamma-synthase. Several genes are up-regulated in response to all four AMPs. Among them is $y j j B$, which encodes a 157-amino-acid, conserved, innermembrane protein predicted to have four trans-membrane helices but with unknown function. An integrated systems biology approach identified at least 1342 genes that are differentially expressed in response to the four AMPs. In E. coli, this accounts for $30 \%$ of the bacterial genome and provides evidence of the wide variety of genes whose expression is altered by AMPs but also of the large number of functions that can be manipulated by the bacteria to acquire AMP resistance [19].

As polycationic peptides, AMPs interact electrostatically with negatively charged bacterial surface structures, including, lipoteichoic acids (gram-positive bacteria), and They then gain access to the cytoplasmic membrane and interact with lipid bilayers, forming transmembrane pores and resulting in a remarkable dose-dependent weakening of the membrane [20]. In addition, the peptide/lipid ratio determines the nature of AMP insertion into the membrane. At high peptide/lipid ratios, AMPs are perpendicularly

$$
\sim 4 \sim
$$


oriented and form transmembrane pores whereas at low ratios the AMPs insert parallel to the bacterial membrane. However, the presence of cholesterol in the lipid membrane may alter the interaction between peptides and phospholipids such that there is reduced disruption of the bilayer and therefore less leakage [21].

Several models have been proposed to specifically explain how AMPs induce membrane permeabilization:

In the barrel-stave model, after their membrane attachment, when a threshold concentration of the AMP is reached, the peptide monomers aggregate to form transmembrane pores within the hydrophobic membrane core. This model is consistent with the mechanism of action of the channel-forming peptide antibiotic alamethicin.

In the toroidal pore model, the AMPs aggregate within the bilayer membranes such that the lipid monolayers to curve around the pore. The hydrophilic region of the AMP joins the bilayer membrane to form the outer part of the pore, while the hydrophobic part of forms its internal aspect. Consequently, the transmembrane pore is bordered by both the lipid head groups and the AMPs, allowing the water core to be lined. This model describes the mechanism of action of magainins (pexiganan, MSI-78) [22] and of LL37 [23].

In the carpet model, AMPs are electrostatically attracted to the anionic phospholipids head groups and "carpet" the surface of the membrane. Thus, high concentrations of AMPs exert detergent-like effects, via the formation of micelles and pores that disrupt the bacterial membrane. However, at a critical concentration, these AMPs form toroidal transient pores [18,20]. This model explains the mode of action of ovispirin, dermaseptin natural analogues, cecropins, trichogin, and some magainins [24].

In the aggregate model, the electrostatic interactions between the phospholipid bilayer and the AMPs is followed by the formation of lipid-peptide complexes that induce the formation of non-specifically oriented pores with heterogeneous shapes and sizes. This allows the AMPs to transiently cross the membrane such that their bacterial-killing effects are related to their interactions with intracellular targets, such as polyanions, DNA or RNA [18,24]. This is the case for the AMPs buforin II, pleurocidin, and dermaseptin, which inhibit DNA or mRNA synthesis.

$$
\sim 5 \sim
$$


However, besides these various forms of membrane permeabilization and intracellular killing, other mechanisms of cell death have been proposed for AMPs, including the inhibition of extracellular biopolymer synthesis and intracellular functions [20,25]. For example, indolicin and PR-39 interfere with protein synthesis and pyrrhocoricin with correct protein folding. The lantibiotics nisin and mersacidin alter peptidoglycan synthesis whereas papiliocin induces the production of oxygen free radicals, which damages both DNA and 'the cell membrane. Finally, other AMPs can inhibit the activity of a few anionic enzymes. As noted above, the wide variety of mechanisms that lead to bacterial killing are consistent with the large number of genes whose expression is altered by AMP challenge. [18].

\subsection{Mechanisms of AMP resistance}

As with the development of antibiotic resistance, bacteria can become resistant to AMPs. The frequency differs widely depending on the bacteria and the peptide [26]. Although the mechanisms of bacterial resistance to AMPs are not yet fully established, modification of the physical-chemical interaction between the AMP and the membrane to prevent permeabilization and the subsequent cellular osmotic imbalance is probably the first step in the development of bacterial resistance. The existence of mechanisms removing the peptides from their site of action has been reported as well as the emergence of new targets[27].

Some microorganisms are able to reduce their net negative charge, either by introducing positively charged groups, such as basic amino acids ( $S$. aureus) or by changing the electronegativity of the cytoplasmic membrane, by diminishing the content of anionic phospholipids (e.g. P. aeruginosa).

Gram-positive pathogens such as Streptococcus agalactiae and Listeria monocytogenes neutralize the anionic charge of their wall by modifying teichoic acids with positively charged D-alanine residues. Other bacteria are surrounded by a capsule of polysaccharides that limits the interaction of AMPs with their targets. These capsuleforming bacteria are more resistant to AMPs than mutants that lack a capsule $[20,26]$.

Among the strategies used by gram-negative bacteria to become resistant to AMPs is to decrease the anionic charge of lipid A (a main component of LPS) by acylation which reduces the fluidity of the outer membrane by increasing the hydrophobic interactions

$$
\sim 6 \sim
$$


(e.g. in E. coli, Salmonella and Haemophilus influenza). Alternatively, they can modify phosphoryl choline, present on the membrane, [20,24,28], or the structure of their outer membrane proteins. The latter is the case in Yersinia enterocolitica, an ability conferred by a $70-\mathrm{kb}$ plasmid [20]. A further mechanism in gram-negative bacteria involves their resistance-nodulation-cell division efflux pumps (RND transporters) and ATP-binding cassette transporters), both of which can pump out AMPs to avoid their action. This mechanism has been well-studied in $E$. coli, in which the yejABEF operon has been related to bacterial uptake of the AMP microcin C, and in Neisseria gonorrhea, in which the loss of the MtrCDE operon results in an enhanced susceptibility to AMPs $[20,28]$. Down-regulation of host AMP expression is also a typical survival strategy of gram-negative pathogens, such as the down-regulation of LL-37 and hBD, produced by the host, 1 by exotoxins of Vibrio cholerae and enterotoxigenic E. coli [28].

Finally, bacterial proteases usually have a broad spectrum of activity against peptides. The production of proteolytic enzymes by either gram-negative or gram-positive bacteria can result in the degradation of active AMP into inactive fragments and therefore AMP resistance. Thus, in gram-negative bacteria, mainly Enterobacteriaceae, the outer membrane protein OmpT of E. coli is able to degrade AMPs [28]. In grampositive $S$. aureus, the same has been demonstrated for aureolysin [20].

\section{THERAPEUTIC APPLICATION OF ANTIMICROBIAL PEPTIDES}

AMPs hold several advantages as antimicrobials as they are less prone to generate microbial resistance than classical antibiotics. As discussed above, they act preferentially (but not exclusively) at the membrane level, may disrupt multiple biochemical processes in the pathogen, and may activate the immune system of the host. Nevertheless, there are still several pitfalls that need to be addressed regarding the development of their broader therapeutic application. These include the toxicity of AMPs, their pharmaceutical and pharmacological optimization (increased stability, reduced clearance rates), and the cost of their production. In fact, very few AMPs have reached the market. Of those that have, the majority are naturally-occurring cyclic peptides that usually contain non-coded amino acids (D-amino acids, for instance).

\section{THE PIPELINE OF ANTIMICROBIAL PEPTIDES}

$\sim 7 \sim$ 


\subsection{Cyclic AMPS}

Currently, there are roughly 20 AMPs in different development phases, from preclinical to clinical phase III trials (Table 2). A few are already clinically available, mainly but not only for topical applications [29].

The first AMPs introduced for clinical use were cyclic compounds. Among those already available for several decades are polymyxins (polymyxin B and colistin, polymyxin E), gramicidin, tyrothricin (tyrocidin is the main component), bacitracin, and daptomycin (Fig. 1). Of these, the first AMP in clinical use in humans was tyrothricin. Discovered by René Dubos in 1939 as an active peptide produced by Bacillus brevis [1], it consists of a mixture of tyrocidine $(\sim 80 \%)$ and gramicidin $(\sim 20 \%)$. Tyrocidine itself is a complex mixture of cyclic peptides (tyrocidines A-D) containing ten amino acids [30]. Due to the toxicity of tyrothricin, it is used only as a topical antimicrobial agent, typically in combination with anesthetic agents (benzocaine, lidocaine, and others), anti-inflammatory drugs (hydrocortisone), or other antibiotics (neomycin). For example, it is found in throat lozenges or sprays used for the treatment of throat irritation and infection [31].

Gramicidins were the first natural antibiotic discovered by means of a systematic, purposeful search for antibacterial compounds [1]. They are particularly effective against gram-positive bacteria and are mostly bacteriostatic, inhibiting bacterial growth, but at high concentrations they are also bactericidal. Gramicidin D is a heterogeneous mixture of three linear antibiotic pentadecapeptides: gramicidin A, B, and C. Like tyrothricin, they are produced by the soil bacterium Bacillus brevis. Gramicidin $\mathrm{S}$ is a cyclic decapeptide that is also active against a few gram-negative bacteria, such as those of the Neisseria genus. Gramicidins cannot be administered systemically because of their pronounced hemolytic side effects. Instead, they are mainly used to treat infected surface wounds as well as ocular, nasal, and throat infections. Gramicidin is also a component of an ophthalmic solution containing the antibiotic neomycin and the AMP polymyxin B [32].

The polymyxins were discovered in 1947 and entered into clinical use in the 1960s, including as systemic drugs. They consist of a mixture of cyclic lipodecapeptides, mainly polymyxin B and colistin (polymyxin E). They are highly active against gramnegative bacteria, particularly most of the ESKAPE bacteria [33]. However, systemic

$$
\sim 8 \sim
$$


use was abandoned beginning in the late 1970s because of reports of their toxicity (mostly nephrotoxicity but also neuromuscular blockage and neurotoxicity) and the availability of new, safer therapeutic options. Thus, today, polymyxins are mostly used for topical applications, in the treatment of eye infections and for selective decontamination of the digestive tract. However, due to the scarcity of new antibiotics against multi-drug-resistant gram-negative bacteria, polymyxins have been rescued as a last resort treatment in patients with serious infections for whom no other therapeutic options exist. In addition, recent clinical studies found that polymyxins have a better therapeutic window than originally reported and therefore that better dosing strategies with fewer secondary effects could be developed. One such strategy is the application of nanotechnologies to produce nanoparticulated polymixins [34,35]. In addition, a great deal of effort is currently being devoted to developing new polymyxin analogs with reduced toxicity [36-39].

Bacitracin is a cyclic peptide antibiotic commonly used in combination with polymyxin and neomycin (an aminoglycoside) as triple antibiotic ointment (Neosporin ${ }^{\mathrm{TM}}$ ) for the topical treatment of skin and eye infections. It is a complex mixture of related cyclopeptides produced by Bacillus subtilis var. Tracy. It was first isolated in 1945 from an infected wound that healed spontaneously in a pediatric patient with a complicated tibial fracture. Parenteral administration of bacitracin is highly restricted because it is nephrotoxic $[32,40]$.

Daptomycin (Cubicin $\left.{ }^{\circledR}\right)$ is also a cyclic lipodepsipeptide antibiotic that is anionic rather than cationic due to the presence of three aspartic acids and one methylglutamic acid not compensated by its single ornithine and kynurenine residues. It was approved by the FDA in 2003 for the treatment of complicated skin and skin-structure infections (cSSSI) caused by susceptible isolates of gram-positive bacteria, particularly S. aureus (also methicillin-resistant strains) and including bloodstream infections by this bacterium (bacteremia) such as in patients with right-sided infective endocarditis [41].

Among the promising analogs of daptomycin is surotomycin, (also known as CB-315, CB-183315, MK4261), obtained from the parent compound by semisynthetic modification of its lipid moiety. Surotomycin is effective in Clostridium difficile, disrupting the bacterial membrane, and is currently in phase III clinical trials for the treatment of C.-difficile-associated diarrhea. Due to its lack of activity against gram-

$$
\sim 9 \sim
$$


negative anaerobes and facultative anaerobes, it minimally disturbs the normal gastrointestinal microbiota. In 2012, it was assigned Qualified Infectious Disease Product (QIDP) status in the USA, under the FDA's GAIN Act, for the treatment of C.difficile-associated diarrhea. This means that priority review, fast-track status, and 5year exclusivity after licensing are applicable [42].

POL7080 (murepavadin) is a cyclic protegrin I analog highly active and selective against protein LptD of $P$. aeruginosa. It has novel mechanism of action, targeting, outer membrane biogenesis. In preclinical studies, POL7080 showed high antimicrobial activity against a broad panel of clinical isolates, including multi-drug resistant Pseudomonas strains. Excellent in vivo efficacy was reported in thigh, lung, and septicemia infection models [43]. Phase I clinical trial in healthy volunteers proved its clinical safety and tolerability, with no serious side effects. It is currently being tested in phase II clinical trials in patients suffering ventilator-associated bacterial pneumonia (VABP) or bronchiectasis [43,44]. In 2014, POL7080 received QIDP status for the treatment of VABP caused by $P$. aeruginosa. A recent phase I clinical trial (September 2016) has been approved to study the drug-drug interactions of POL7080 and amikacin [45].

\subsection{Linear AMPs}

In addition to cyclic analogs, several linear AMPs are at different stages of development (Fig. 2) $[29,38,46]$.

Pexiganan, a 22-amino acid magainin analog, active against a broad spectrum of grampositive and gram-negative aerobic and anaerobic bacteria as well as fungi. In addition, it is active against several strains of resistant bacteria, including methicillin-resistant $S$. aureus (MRSA), vancomycin-resistant Enterococcus (VRE), producers of extendedspectrum beta-lactamases (ESBL), and several multidrug resistant bacteria. Pivotal phase III clinical trials were initiated for pexiganan (Locilex, pexiganan cream $0.8 \%$; Dipexium Pharmaceuticals) for the treatment of mild infections of diabetic foot ulcers. However, in October 2016, the manufacturer announced that top-line data from the OneStep Phase III trial of Locilex ${ }^{\circledR}$ did not meet establish the superiority of the drug (the primary clinical endpoint) versus vehicle plus standardized wound care. Thus,

$$
\sim 10 \sim
$$


Locilex is now being tested for use in skin and cSSI, such as infected surgical wounds, infected burns, and infected decubitus ulcers (pressure sores) [47].

Omiganan (CLS001 or MBI-226), a cationic dodecapeptide derived from indolicin (isolated from bovine neutrophils), exhibits activity against gram-positive and gramnegative bacteria as well as fungi. It is currently in phase II clinical trials for the treatment of acne vulgaris atopic dermatitis, genital warts, skin inflammation, and vulvar intraepithelial neoplasia. A phase III trial is underway testing omiganan for the topical treatment of the papules and pustules of rosacea, a chronic skin disease that affects over 14 million North- Americans and 45 million people globally [48].

SGX942 (dusquetide), also derived from indolicin, is a fully synthetic, 5-amino acid peptide that acts as an innate defense regulator. Its safety and tolerability have been demonstrated in healthy volunteers (phase I clinical trial). It was granted Fast Track status from the FDA for the treatment of oral mucositis caused by radiation and/or chemotherapy treatment in head and neck cancer patients [49]. A phase II clinical study of this application was completed at the end of 2016. Preclinical data indicated that SGX94 is active in models of a wide range of therapeutic indications, including the severe side effects of chemo- and/or radiation-therapy and inflammation. [50].

LTX-109 (Lytixar) is a short cationic peptidomimetic developed for topical treatments. Its fast-acting bactericidal mode of action is due to the selective and ultra-rapid disruption of microbial membranes. It is in phase I/II trial for the treatment of treatment of mild diabetic foot infections and nasal decolonization of $S$. aureus, including MRSA. Another phase II clinical trial is examining its use in the treatment of uncomplicated, gram-positive, skin infection and impetigo [51].

The Karolinska Institut, Karolinska Development AB (Sweden) and its portfolio company, Promore Pharma (former Pergamum AB), are the owners of three clinicalstage peptides (LL-37, PXL01 and DPK-060) developed for topical applications. These compounds are multifunctional, exhibiting broad antimicrobial activity but also modulating inflammation, immune functions, and wound-healing properties. They are thus intended for the treatment of chronic wounds, the prevention of scarring and adhesions, and, as antimicrobial agents. LL-37 (hCAP-18, derived from human cathelidicin) is being tested in a phase II clinical trial for the treatment venous leg ulcers. The results obtained thus far indicate a significantly improved healing rate 
compared to placebo. Its enantiomer (D-LL-37) also shows broad-spectrum antibacterial activity, suggesting an unspecific mode of action of these compounds. A phase II clinical trial examining the use of PXL-01 in the prevention of post-surgical adhesions yielded a positive outcome and a phase III clinical trial has been started. A statistically significant improvement was also reported in a phase II clinical trial of DPK-060 in outer ear infections [52].

Brilacidin is an arylamide foldamer peptidomimetic small molecule synthetically derived from human defensins. It shows high antibiotic activity against both grampositive and gram-negative bacteria. A clinical phase IIb study comparing brilacidin to daptomycin for the treatment of acute bacterial skin and skin structure infections (ABSSSI) yielded excellent positive results. Brilacidin received QIDP designation in 2012. In January 2016, Cellceutix announced a pivotal phase III trial of brilacidin for the treatment of ABSSSI infections caused by gram-positive bacteria [53].

The AMP C16G2 was designed to specifically target Streptococcus mutans, the acidproducing bacterium associated with dental caries and tooth decay. The peptide contains two functional regions: an S.-mutans-selective targeting region and a broad-spectrum antimicrobial peptide (G2). Although it is bactericidal, via a membrane disruption mechanism similar to that of other AMPs, it does not affect other species in the oral biofilm. The target indication for $\mathrm{C} 16 \mathrm{G} 2$ is the prevention of dental caries and related diseases of the oral cavity caused by microbial dysbiosis.. C16G2 (administered as a dental gel) successfully completed a phase II clinical trial as an anti-cavity drug [54,55].

HB1345 (Helix Biomedix) is a synthetic lipohexapeptide with potent and broad spectrum antimicrobial activity when applied topically to skin infections. Its minimum inhibitory concentration (MIC) values against key pathogens, including Propionibacterium acnes, are in the $1-2 \mu \mathrm{g} / \mathrm{ml}$ range. HB1345 is in the preclinical phase for the treatment of acne, the lead indication chosen for this compound, based on its binding of lipoteichoic acid, involved in the inflammation that develops in acne. Similarly, HB1275 is a lipohexapeptide (no sequence disclosed) in the preclinical stage of development based on its potent antifungal activity against yeast and filamentous fungi, particularly Trichophyton (athlete's foot, tinea capitis, and onychomycosis) [56] 
Arenicin-3 is a 21 -residue amphipathic $\beta$-hairpin peptide that contains two disulfide bridges. Isolated from the marine lugworm Arenicola marina, it binds to and disrupts the integrity of the outer and cytoplasmic membranes of gram-negative bacteria. The arenicin-3 analog AA139 is highly active against gram-negative ESKAPE pathogens, including multi-drug resistant strains, and is currently in pre-clinical development. Among the possible applications are the treatment of urinary tract infections caused by E. coli strains (currently being tested by Adenium Biotech) and of both hospitalacquired and ventilation-associated pneumonia [57].

\subsection{Lantibiotics}

Lantibiotics are a naturally occurring class of AMPs that contain lanthionine, a nonproteinogenic amino acid, These antimicrobials are produced by bacteria and include nisin, which is used as a food preservative (E324). However, lantibiotics are also in development to fight infections. The main difficulty their large-scale production, as standard fermentation methods typically result in only minute amounts. A few candidates are available, such as OG253 and OG716 (no structures disclosed). OG235, obtained from the Oragenics discovery platform, has shown efficacy in an animal model of $C$. difficile enteritis (nonclinical testing). In 2015, it was at the FDA's preInvestigational New Drug application stage. In August 2016, Oragenics announced positive results for OG716, a second-generation orally-active lantibiotic obtained from its Mutacin 1140 (MU1140) platform. Promising in vivo efficacy was reported, including decreased relapse and the reduced production of $C$. difficile spores compared to a vancomycin positive control[58].

The lantibiotic NVB333 is a semi-synthetic derivative of the lantibiotic deoxyactagardine that exerts its antimicrobial activity by inhibiting cell wall biosynthesis. NVB333 is under development for the systemic treatment of grampositive infections, including those caused by MRSA. It has also been proven to be active against strains resistant to currently available antibiotics, such as vancomycin, daptomycin, and linezolid. In vivo tests have shown high activity in murine models of thigh and lung infections and promising preliminary toxicology results [59].

\section{SYNERGIMS AMONG AMPS}


Due to their mechanism of action, in which the primary target is the bacterial membrane, AMPs are often effective against multiresistant bacteria. They are therefore excellent molecules to be combined with other antimicrobials to achieve more effective synergistic effects. For example, AMPs can be combined with antibiotics of low bacterial penetrability or when the mechanism of resistance involves the membrane.

A study of the use of colistin in combination with an antibiotic allowed both a reduction of the effective dose of colistin and the increased activity of the combined antimicrobials. Moreover, synergies of colistin with different antibiotics have been described, including quinolones fosfomycin, and aminoglucosides [60].

Other unusual combinations of antimicrobials have been tested, some with promising results. For example, linezolid and glycopeptides are antimicrobials used in to treat infections caused by gram-positive bacteria (gram-negatives are intrinsically resistant to these antimicrobials). Synergism between colistin and linezolid was demonstrated in vitro against $A$. baumannii clinical strains [61]. Colistin combined with glycopeptides was synergistic in vitro and in a Galleria mellonella model [62].

Among the most studied AMP synergies are colistin-carbapenem ( $\beta$-lactams) $[63,64]$ and, especially, AMPs with imipenem. The main mechanism of resistance to imipenem is a decrease in bacterial membrane permeability due to the lack of OprD, a porin used by imipenem to penetrate the outer membrane. The combination of imipenem with AMP could restore the ability of the former to penetrate the bacterial cell and thus bacterial susceptibility [37,65]. Rudilla et al. demonstrated the synergy between colistin-derived AMP38 and carbapenems in imipenem-resistant strains of $P$. aeruginosa [37]. In general, synergy has been observed with many polymyxin analogues. Particularly good results have been obtained in their potentiation of the activity of large hydrophobic antibiotics, such as the macrolides azithromycin and erythromycin [26].

The in vitro synergistic antibacterial activity of six proline-based cyclic dipeptides of natural origin [cyclo(D-Pro-L-Leu), cyclo(L-Pro-L-Met), cyclo(D-Pro-L-Phe), cyclo(LPro-L-Phe), cyclo(L- Pro-L-Tyr), and cyclo(L-Pro-D-Tyr)] with $\beta$-lactamic antibiotics was reported by Kumar et al [66]. A synergistic effect of antibiotics with several newly developed short AMPs was described by Wang et al., who examined the combined activity of PMAP-36 and PRW4 with aminoglycosides [67]. 
The magainin analogue pexiganan MSI-78 is a 22-amino acid amphipathic peptide that showed synergy in combination with $\beta$-lactam antibiotics[68], suggesting its use against infections caused by P. aeruginosa, E. coli, S. aureus, and S. epidermidis.

The short AMP iseganan IB-367 (17-amino acid peptide) contains an amidated Cterminus and two disulfide bridges (Cys5-Cys14 and Cys7-Cys12). Synergies between IB-367 and the cyclic AMP colistin in P. aeruginosa, E. coli, A. baumannii, and K. pneumoniae were demonstrated in an in vitro checkerboard assay [69].

Nisin and its derivatives, nisin V (M21V) and nisin I4V, are lantibiotics with potent antibacterial activity against many gram-positive bacteria. Analysis by kill curves established that nisin $\mathrm{V}+$ penicillin or nisin $\mathrm{I} 4 \mathrm{~V}+$ chloramphenicol had enhanced inhibitory effects against $S$. aureus and $S$. pseudintermedius, respectively, compared to the equivalent nisin $\mathrm{A}$ or when each antimicrobial was administered alone. These peptides have been used mainly in food microbiology [70]

The synergy of AMPs with $\beta$-lactam inhibitors recommends the further investigation of these and other such combinations to enhance the activity of "classical" antimicrobial agents whose efficacy when used alone has been compromised by the emergence of resistant strains.

\section{AMPs and BIOFILMS}

Most pathogens have the ability to form stable biofilms, which are a common cause of both persistent and device-associated infections. Because bacteria in biofilms are much less sensitive to antimicrobial agents than planktonic microbes the treatment of biofilmtype infections often fails. However, most AMPs are active against both planktonic and biofilm-forming bacteria, as demonstrated for KT2 and RT2, the semisynthetic peptide SB056, peptide 1018, and others. Other AMPs, such as LL-37, possess weak planktonic activity but show strong activity against biofilms [37,71]. Moreover, in addition to their ability to penetrate bacterial biofilms many AMPs prevent biofilm formation [18].

AMPs also enhance the activity of other antimicrobial agents when they are used in combination to treat infections involving biofilms. The broad-spectrum of activity shown by anti-biofilm AMPs includes interference with second messenger molecules and therefore signaling pathways, in both gram-positive and gram-negative bacteria [71]. 
However, several mechanisms of AMP resistance exhibited by biofilm bacteria have been described and threaten the effective use of these molecules. For instance, different bacterial subpopulations in the biofilm may differ in their motility or metabolism and thus be more resistant than others to AMPs. The development of resistance is also favored by the higher mutation rate of bacteria in biofilm communities than growing planktonically. The up-regulation of efflux pumps or operon genes in biofilms (e.g., the pmr operon of $P$. aeruginosa) can also lead to high levels of AMP resistance [72,73]. The ability of the biofilm itself to reduce the diffusion of large AMPs (periplasmic glucan in $P$. aeruginosa biofilms) has also been demonstrated, but whether the diffusion rates of all types of AMPs are affected remains to be determined [73].

Despite these possible mechanisms of biofilm resistance, AMPs represent a novel and promising approach for the eradication of gram-positive and gram-negative bacteria in biofilms, which are mainly a feature of chronic and long-term infections. Additional work is needed to better understand the downstream processes of antibiofilm AMPs to allow the optimization of these drugs, when used either alone or in combination with other antimicrobial agents [71].

\section{ANTI-MYCOBACTERIAL PEPTIDES}

No novel drugs against Mycobacterium sp. have been introduced for clinical use in the past 40 years. AMPs offer a new approach and most of those investigated thus far for their efficacy against Mycobacterium spp. are either natural peptides or derived from natural peptides $[74,75]$. Several examples are provided in the following:

Defensins such as HNP1-4 are human neutrophil peptides active on skin or other epithelial surfaces, usually in the presence of low concentrations of salt. HNPs kill mycobacteria probably by inhibiting the biosynthesis of macromolecules and/or increasing the permeability of the bacterial cell membrane [74]

Lactoferrins are iron-binding proteins belonging to the transferrin family of proteins. Silva et al [76] studied the activity of human and bovine lactoferrins, including hLFcin1-11, LFcin17-30, and other variants obtained by specific amino acid substitutions, reporting promising results with some of these peptides.

$$
\sim 16 \sim
$$


Cathelicidin or its terminal region (LL-37), an AMP already mentioned in this review, shows moderate activity against Mycobacterium tuberculosis $\mathrm{H} 37 \mathrm{Rv}$ strains as well as Mycobacterium tuberculosis multidrug resistant strains, Its MIC is between 2 and 10 $\mu \mathrm{g} / \mathrm{ml}$. Rivas-Santiago et al. also showed the activity of three LL37-related peptides: E2, E6, and CP26 [77].

Several synthetic peptides with antimycobacterial activity have been developed, including D-LAK peptides, which are linear, cationic, amphipathic $\alpha$-helix-shaped AMPs [78] that at low concentrations have extracellular antimycobacterial activity; however, despite mild cytotoxicity against THP-1 cells they failed in completely eradicating intracellular mycobacteria.

A library of small ( $\sim 10$ amino acids) synthetic AMPs, has been tested and some of the peptides exhibit interesting activities against M. tuberculosis and M. smegmatis . Their MIC values were as low as $1.1 \mu \mathrm{M}$ and cytotoxicity against THP-1 cells was low [79] .

\section{ANTIFUNGAL PEPTIDES}

Echinocandins are antifungal peptides that show fungicidal activity against Candida spp and fungistatic activity against Aspergillus spp. [80]. Many have been approved by the FDA and EMEA (European Medicine Agency) Caspofungin (Merck), Anidulafungin (Pfizer), and Micafungin (Astellas) have been available since the early 2000s and are widely used for the treatment of systemic candidemia and candidiasis. All of them are cyclic hexapeptides linked with a fatty acid chain (semisynthetic peptides) and were derived from pneumocandins (natural lipopeptides).

NP213 is a cyclic arginine-based heptamer (Table 2) with fungicidal activity. As the active ingredient of Novexatin ${ }^{\circledR}$, it has been formulated as a brush-on-treatment for fungal nail infections (onychomycosis). Phase I and IIa clinical studies demonstrated that NP213 is safe, well-tolerated, and effective. Novabiotics is also developing Novamycin (NP339), a novel antifungal peptide for the treatment of aspergillosis, candidiasis , and cryptococcosis, as well as Novarifyn (NP432), an antibacterial peptide to treat infections by pathogens such as MRSA, $P$. aeruginosa, C. difficile, A. baumannii, and E. coli. Both are expected to undergo initial clinical studies in 2017 [81]. 
P113 (Table 2) is a 12-amino-acid cationic and amphipathic AMP derived from naturally occurring histatin 5 , an oral defense protein found in saliva. Clinical phase I and II results showed that P113 is safe and effective in the treatment of gingivitis and oral candidiasis. In addition, non-prescription over-the-counter products containing P113, including a mouthwash, oral spray, and anti-bacterial hand cream, have recently become available [82]

Qi et al. [83] described a series of short (9-11 amino acids) linear peptide with an $\alpha$ helical structure. Some (P11-5, P11-6, and P9-4) have shown promising activity against the yeast Candida albicans ( $\mathrm{MIC}=3.1 \mu \mathrm{g} / \mathrm{ml}$ ) and against the filamentous fungi Fusarium solani (MICs $=12.5-50 \mu \mathrm{g} / \mathrm{ml}$ ). Importantly, both of these antifungal peptides are of low toxicity.

\section{ANTI-PARASITIC PEPTIDES}

The diversity of parasitic groups, with their complex life cycles that typically involve multiple stages in different hosts and their enormously different protein expression and membrane composition, have hindered the rapid development of AMPs for the treatment of parasitic disease [84].

Nevertheless, a broad range of AMPs (both naturally occurring peptides and their structural analogues) has been shown to be effective against a variety of parasitic infections caused by protozoa (Chagas disease, human African trypanosomiasis, malaria, and leishmaniosis), and helminths (taeniasis and onchocerciasis). Moreover, some of these microbes, for example the filarial worm Onchocerca volvulus, may be a source of novel AMPs with therapeutic potential against microbial infections [85].

A few examples of AMPs effective against parasitic diseases are provided in the following.

\subsection{Plasmodium}

Magainin-2 was one of the first anti-protozoal host defense peptide to be identified: Its anti-plasmodium activity was described over 35 years ago [86]. The inhibition of Plasmodium falciparum growth by the hybrid peptide cecropin-melittin (CA 1-13 and H 1-13) has also been reported [87]. 
Other anti-malarial peptides produced by insects are defensins (drosomycins), gambicins, and gomesin. Dermaseptins, of amphibian origin, are highly active against P. falciparum. A high level of antiplasmodial activity has been demonstrated for the acyl-derivative desmapeptin K4-S4 [88].

Scorpine, a peptide isolated from scorpion and spider's venom, also has inhibitory activity against P. falciparum parasitemia, as do the synthetic antimalarial AMPs NK-2, D-HALO-rev, and IDR-1018. Some antimalarial peptides act selectively on infected erythrocytes, leaving the membranes of healthy cells undisturbed and are thus of particular interest as antimalarial drugs [89]. Their development is highly anticipated because artemisinin-resistance is becoming increasingly frequent, especially in Asia [90].

\subsection{Trypanosoma brucei}

AMPs have a clear established role in the immunity of the African trypanosomiasis vector (tse-tse fly). For example, attacin, defensin, and cecropin participate in the insect's innate immunity. Conversely, several trypanocidal peptides from mammalian hosts have also been described, including the $\alpha$ - and $\beta$ defensins and cathelicidins ( sheep SMAP-29 and pig protegrin-1). All of then show in vitro trypanolytic activity against both procyclic and bloodstream forms of Trypanosoma brucei [91]. Peptide antibiotics isolated from fungi (leucinostatin A and B, alamethicin and tsushimycin) also exhibit trypanolytic activity both in vitro and in vivo, although in some cases with a high oral toxicity.

Among the synthetic AMPs targeting T. brucei are the cell penetrating peptide transportan TP10, a derivate of bovine BMAP-27, and small synthetic peptides derived from insect defensins. In addition, unconventional AMPs, such as neuropetides, trypanosome lytic factor, and small hydrophobic peptides (SHP-1 and SHP-2), kill African trypanosomes mainly by increasing the rigidity of their membranes [92].

\subsection{Trypanosoma cruzi}

Three classes of anti-trypanosomal peptides from insect sources have been extensively studied: apidecins, cecropins, and melittins. Cecropin and melittin, used as a hybrid in the treatment of malaria, have been combined with magainin 2 as an anti-trypanocidal agent with activity 10-fold higher than when used alone. The synthetic cecropins SB-37 
and Shiva-1 are 10 times more effective than natural cecropins in damaging and killing the parasite.

Temporin peptides, the smallest amphipathic $\alpha$-helical containing AMPs found in nature, are produced by frogs, which like other amphibians are naturally resistant to Trypanosoma cruzi infection. Temporin-SHd has significant inhibitory effect against trypanosomes but its toxicity to human cells has discouraged its use. Temporizin-1 is an artificial hybrid peptide containing pore-forming gramicidin but with a reduction in the region that inserts into membranes. Its moderate toxicity towards mammalian cells and improved anti-trypanosomal activity recommend its further development as a novel anti-trypanosomal drugs [93].

\subsection{Leishmania}

Leishmanicidal peptides include temporins, bombins, magainins, and cathelicidins [94]. Dermaseptin S4 and its synthetic analogues potently induce the lysis of promastigotes. Anti- Leishmania activity has been demonstrated for the AMPs gomesin, indolicin, and thionins, isolated from different organisms. Pexiganan a synthetic magainin-based lysine-rich peptide, originally tested in a phase 3 clinical trial for diabetic foot ulcers but was also found to induce apoptosis in leishmanial promastigotes.

Trichomonas and the intracellular parasites Criptosporidium parvum and C. hominis can also be killed by AMPs/HDPs.

Peptide drugs for protozoan diseases are still in the early stages of testing, but the available evidence suggests that they will be effective in the treatment of malaria and other diseases. However, the continued development of AMPs for use in the treatment of Plasmodium or leishmanial infections depends on several factors, including a reduction of the high production costs, and an improvement of the stability of the drugs, and a reduction of the required dose, to avoid toxicity [95]. A promising strategy is the use of nanotechnologies and peptide encapsulation to increase the selectivity and halflife of the drug.

\subsection{Taeniasis and cysticercosis}

Temporin A and iseganan IB-367 (a protegrin-1 derivative of the cathelicidins family) have antiparasitic effects against Taenia crassiceps, the causative agent of tapeworm. In

$$
\sim 20 \sim
$$


in vitro tests, both drugs damage the tegumentary surface of the cysticerci to induce morphological changes [96].

\subsection{Onchocerca volvulus}

Extracts of $O$. volvulus obtained from infected patients were shown to also contain a human neutrophil peptide 1-3 (HNP 1-3), a defensin that mediates the macrophage response to microorganisms. HNP 1-3 binds to the surface of $O$. volvulus, which is not affected by the peptide. Others excretory/secretory products of Onchocerca were found to have significant antibacterial activity against Escherichia coli.

Helminth defense molecules (HDMs) are a novel family of molecules secreted by helminthic parasites and exhibiting structural and biochemical characteristics similar to those of mammalian helminth defense peptides (HDPs) [97]. A comparison of four trematode cathelicidin-like HDMs derived from Schistosoma mansoni and Fasciola hepatica showed that unlike HDPs, they exhibit no antimicrobial activity and are noncytotoxic to mammalian cells (macrophages and red blood cells). However, both HDPs and HDMs suppress the activation of macrophages by microbial stimuli and alter the response of B cells to cytokine stimulation. These observations suggest that HDMs are a novel family of HDPs that evolved to regulate the immune responses of their mammalian hosts, by retaining potent immune modulatory properties without causing deleterious cytotoxic effects. This strategy allows helminths to modulate host immune responses in establishing an environment that facilitates the reproduction and survival of the parasite [98]. A phylogenetic analysis revealed that HDMs are conserved across the majority of trematode species, including liver flukes and blood flukes.

In summary, HDMs hold promise as a more attractive therapeutic option than HDPs, as they show all the potent immunomodulatory effects of the latter without their cytotoxic and cytolytic effects.

\section{CONCLUSION}

Given the ubiquity of AMPs in nature and their production by almost all living organism, these peptides and their synthetic derivatives have become an interesting alternative to traditional antibiotics. This has been well-demonstrated by the renewed use of colistin as a first-line antimicrobial to treat severe infections caused by 
multidrug-resistant microorganisms. Moreover, the AMP pipeline currently includes over 20 different compounds in all clinical stages of development.

The importance of AMPs lies in their multiple mechanisms of action to produce a killing effect. This may prevent the development of bacterial resistance, which generally relies on more than a single mutational or adaptive event. Furthermore, the ability of AMPs to disrupt the bacterial membrane and thus alter its permeability makes them interesting compounds for use in synergistic combinations with other antimicrobial agents.

\section{EXPERT OPINION}

Antimicrobial peptides, also called host defense peptides (HDPs), were first discovered on the external surface of amphibians, in studies of why their nutritive and humid surface was not permanently infected, Since then these small molecules have been shown to form part of the innate immune response of almost (if not all) classes of life [99]. For instance, the polymorphonuclear neutrophils and natural killer cells of vertebrates produce AMPs active against microbes (including protozoa, fungi, and bacteria) and even tumor cells. Among bacteria, the genus Bacillus produces several AMPs of interest in human medicine, such as tyrothricin, gramicidin $\mathrm{D}$, polymyxin $\mathrm{B}$, and colistin. Indeed, the widely used antibiotic bacitracin is a mixture of bacterial AMPs. Among the other bacterial species that produce AMPs is Lactobacillus, whose peptides are extensively used in the food industry, including as L-antibiotics (nisin, lactacin, etc.) [70]. Also of interest are microcins, a family of plasmid-encoded AMPs secreted by Enterobacteria [100]. Fungal AMPs include the peptaibol family of peptides, which contain unusual amino acids. AMPs are also produced by plants and participate in plant defense (defensins) responses. Within the animal kingdom, AMP production is almost universal, with humoral defense peptides described in sponges, cnidarians, and mollusks. In these invertebrates living in marine and freshwater environments, AMPs are a fundamental strategy guaranteeing their survival. Among the AMPs prodced by arthropods are the positive charged cecropins, thanatin, melittin, apidaecins, and ceratotoxins. The defense strategies of fish also rely on AMPs [99], as demonstrated by cathelicidins and $\beta$-defensins, piscidins, and hepcidins, whose chemical structures and mechanisms of action are highly diverse. Amphibians produce many AMPs, including bombinins, cathelicidins, and dermaseptin, whose mechanisms 
of action are highly diverse. Reptiles and birds, like other vertebrates, also produce AMPs belonging to the cathelicidin and defensin families. Besides AMPs belonging to the cathelicidin and defensin families, non-human mammals produce other wellcharacterized AMPs, such as platelet antimicrobial proteins (PMPs), dermcidin, and hepcidins [99]. It remains unclear to what extent these AMPs play a central role in the highly evolved immune response of mammalians, although, in some cases, such as LL37 an amphipathic molecule that acquires an $\alpha$-helical structure when interacting with cell membranes to form transmembrane pores, their role has been very well recognized.

An appreciation of the diversity of AMPs in nature has stimulated the development of synthetic derivatives in the laboratory. They are gaining increasing importance given the dramatic rise in resistant bacteria [36], although both their antimicrobial action and cellular toxicity must be well-defined. Nonetheless, given the scarcity of new natural antimicrobials, synthetic AMPs are sure to be a promising path with which to improve the therapeutic arsenal against infectious diseases.

\section{ACKNOWLEDGEMENTS}

We thank the University of Barcelona, Fundació Bosch i Gimpera, Xarxa de Referència en Biotecnologia (XRB, Generalitat de Catalunya) and the European Institute of Innovation and Technology (EIT Health) for their support. FR and MV are members of the ENABLE (European Gram-Negative Antibacterial Engine) European consortium (IMI-ND4BB, http://www.imi.europa.eu/content/enable).

We thank Dr Wendy Ran for editing the manuscript.

\section{FUNDING}

Own resources

\section{DECLARATION OF INTEREST}

None to declare

\section{REFERENCES}

[1] Van Epps HL. René Dubos: unearthing antibiotics. J. Exp. Med.2006;203:259.

[2] Davies J. Where have All the Antibiotics Gone? Can. J. Infect. Dis. Med. 
Microbiol. 2006;17:287-290.

[3] Ruiz-Martínez L, López-Jiménez L, d'Ostuni V, et al. A mechanism of carbapenem resistance due to a new insertion element (ISPa133) in Pseudomonas aeruginosa. Int. Microbiol. 2011;14:51-58.

[4] Madec J-Y, Haenni M, Nordmann P, et al. ESBL/AmpC- and carbapenemaseproducing Enterobacteriaceae in animals: a threat for humans? Clin. Microbiol. Infect.2017 Published online 28 January 2017 DOI:http://dx.doi.org/10.1016/j.cmi.2017.01.013;

[5] Li Y, Metcalf BJ, Chochua S, et al. Penicillin-Binding Protein Transpeptidase Signatures for Tracking and Predicting $\beta$-Lactam Resistance Levels in Streptococcus pneumoniae. MBio. 2016;7:e00756-16.

[6] Mendelman PM, Caugant DA, Kalaitzoglou G, et al. Genetic diversity of penicillin G-resistant Neisseria meningitidis from Spain. Infect. Immun. 1989;57:1025-1029.

[7] Nikaido H, Pagès J-M. Broad-specificity efflux pumps and their role in multidrug resistance of Gram-negative bacteria. FEMS Microbiol. Rev. 2012 ;36:340-363.

[8] Algburi A, Comito N, Kashtanov D, et al. Control of Biofilm Formation: Antibiotics and Beyond. Appl. Environ. Microbiol. 2017;83:e02508-16.

[9] Enright MC, Robinson DA, Randle G, et al. The evolutionary history of methicillin-resistant Staphylococcus aureus (MRSA). Proc. Natl. Acad. Sci. U. S. A. 2002;99:7687-7692.

[10] Springer B, Kidan YG, Prammananan T, et al. Mechanisms of streptomycin resistance: selection of mutations in the $16 \mathrm{~S}$ rRNA gene conferring resistance. Antimicrob. Agents Chemother. 2001;45:2877-2884.

[11] Humphries RM, Pollett S, Sakoulas G. A current perspective on daptomycin for the clinical microbiologist. Clin. Microbiol. Rev. 2013;26:759-780.

[12] O’Neil J. Tackling Drug-Resistant Infections Globally: final report and recommendations . 
Available from: https://amr-review.org/sites/default/files/160525_Final paper_with cover.pdf. [Last accessed 5 December 20165].

[13] Boucher HW, Talbot GH, Bradley JS, et al. Bad Bugs, No Drugs: No ESKAPE! An Update from the Infectious Diseases Society of America. Clin. Infect. Dis. 2009;48:1-12.

[14] EDCD, antimicrobial-resistance-europe-2014 .

Available from: http://ecdc.europa.eu/en/publications/Publications/antimicrobialresistance-europe-2014.pdf. [Last accessed 1 November 2016]

$* *$ The results presented in this report are based on antimicrobial resistance data from invasive isolates reported to EARS-Net by $29 \mathrm{EU} / \mathrm{EEA}$ countries in 2015 (data referring to 2014)

[15] Davies J, Davies D. Origins and evolution of antibiotic resistance. Microbiol. Mol. Biol. Rev. 2010;74:417-433.

[16] Jenssen H, Hamill P, Hancock REW. Peptide antimicrobial agents. Clin. Microbiol. Rev. 2006;19:491-511.

[17] Karaiskos I, Souli M, Galani I, et al. Colistin: still a lifesaver for the 21st century? Expert Opin. Drug Metab. Toxicol. 2016;1-13.

[18] Rios AC, Moutinho CG, Pinto FC, et al. Alternatives to overcoming bacterial resistances: State-of-the-art. Microbiol. Res. 2016;191:51-80.

[19] Kozlowska J, Vermeer LS, Rogers GB, et al. Combined systems approaches reveal highly plastic responses to antimicrobial peptide challenge in Escherichia coli. PLoS Pathog. 2014;10:e1004104.

[20] Brogden KA. Antimicrobial peptides: pore formers or metabolic inhibitors in bacteria? Nat. Rev. Microbiol. 2005;3:238-250.

* A broad overview describing the resistance strategies that microorganisms use to circumvent antimicrobial killing and the different mechanisms of antimicrobial-peptide-induced pore formation.

$$
\sim 25 \sim
$$


[21] Epand RF, Ramamoorthy A, Epand RM. Membrane lipid composition and the interaction of pardaxin: the role of cholesterol. Protein Pept. Lett. 2006;13:1-5.

[22] Hallock KJ, Lee D-K, Ramamoorthy A. MSI-78, an analogue of the magainin antimicrobial peptides, disrupts lipid bilayer structure via positive curvature strain. Biophys. J. 2003;84:3052-3060.

[23] Katherine A. Henzler-Wildman $\ddagger$, $\perp$, Gary V. Martinez $\S$, Michael F. Brown $\S$ and, et al. Perturbation of the Hydrophobic Core of Lipid Bilayers by the Human Antimicrobial Peptide LL-37. 2004;43:8459-69.

[24] Teixeira V, Feio MJ, Bastos M. Role of lipids in the interaction of antimicrobial peptides with membranes. Prog. Lipid Res. 2012;51:149-177.

* A detailed description of the role of the composition of lipids in the antimicrobial peptides activity and bacterial membrane permeabilization.

[25] Yeaman MR, Yount NY. Mechanisms of antimicrobial peptide action and resistance. Pharmacol. Rev. 2003;55:27-55.

[26] Hassan M, Kjos M, Nes IF, et al. Natural antimicrobial peptides from bacteria: characteristics and potential applications to fight against antibiotic resistance. J. Appl. Microbiol. 2012;113:723-736.

[27] Nguyen LT, Haney EF, Vogel HJ. The expanding scope of antimicrobial peptide structures and their modes of action. Trends Biotechnol. 2011;29:464-472.

[28] Gruenheid S, Moual H. Resistance to antimicrobial peptides in Gram-negative bacteria. FEMS Microbiol. Lett.. 2012;330:81-89.

** This study describes the most relevant mechanisms by which Gram-negative pathogens resist AMPs. Among them, AMPs can be inactivated by bacterial and host proteases; LPS modifications and presence of capsule can prevent the interaction of AMP with bacterial membrane; AMPs can be pumped in or out of bacteria by efflux pumps and AMPs can suppress their expression by host cells

[29] Rabanal, Francesc; Cajal Y. Therapeutic Potential of Antimicrobial Peptide. In: Villa TG, Vinas M, editors. New Weapons to Control Bact. Growth Ed: Springer International Publishing; 2016

$$
\sim 26 \sim
$$


[30] Tang X-J, Thibault P, Boyd RK. Characterisation of the tyrocidine and gramicidin fractions of the tyrothricin complex from Bacillus brevis using liquid chromatography and mass spectrometry. Int. J. Mass Spectrom. Ion Process. 1992;122:153-179.

[31] Tyrothricin - Drugs.com

Available from: https://www.drugs.com/international/tyrothricin.html. [Last accessed 13 November 2016 ].

[32] Stevenson CL. Advances in Peptide Pharmaceuticals. Curr. Pharm. Biotechnol. 2009. p. 122-137.

[33] Boucher HW, Talbot GH, Benjamin DK, et al. 10 x '20 Progress--development of new drugs active against gram-negative bacilli: an update from the Infectious Diseases Society of America. Clin. Infect. Dis. 2013;56:1685-1694.

[34] Pastor M, Moreno-Sastre M, Esquisabel A, et al. Sodium colistimethate loaded lipid nanocarriers for the treatment of Pseudomonas aeruginosa infections associated with cystic fibrosis. Int. J. Pharm. 2014;477:485-494.

[35] Sans-Serramitjana E, Fusté E, Martínez-Garriga B, et al. Killing effect of nanoencapsulated colistin sulfate on Pseudomonas aeruginosa from cystic fibrosis patients. J. Cyst. Fibros. 2016;15:611-618.

[36] Rabanal F, Grau-Campistany A, Vila-Farrés X, et al. A bioinspired peptide scaffold with high antibiotic activity and low in vivo toxicity. Sci. Rep. 2015;5:10558.

**New design of polymyxin analogs modifying not only the amino acid sequence but also introducing disulfide bonds within the peptide scaffold to reduce toxicity and facilitate metabolization upon accumulation in renal cells, the suspected cause of nephrotoxicity.

[37] Rudilla H, Fusté E, Cajal Y, et al. Synergistic Antipseudomonal Effects of Synthetic Peptide AMP38 and Carbapenems. Molecules. 2016;21:1223.

[38] Grau-Campistany A, Pujol M, Marqués AM, et al. Membrane interaction of a new synthetic antimicrobial lipopeptide sp- 85 with broad spectrum activity.

$$
\sim 27 \sim
$$


Colloids Surfaces A Physicochem. Eng. Asp. 2015;480:307-317.

[39] Grau-Campistany A, Manresa Á, Pujol M, et al. Tryptophan-containing lipopeptide antibiotics derived from polymyxin B with activity against Gram positive and Gram negative bacteria. Biochim. Biophys. Acta. 2016;1858:333343.

[40] Bacitracin. Available from: http://www.drugbank.ca/drugs/DB00626. [Last accessed 8 November 2016 ].

[41] CUBICIN® webpage. Available from: http://cubicin.com/. [Last accessed 5 November 2016].

[42] Knight-Connoni V, Mascio C, Chesnel L, et al. Discovery and development of surotomycin for the treatment of Clostridium difficile. J. Ind. Microbiol.

Biotechnol. 2016;43:195-204.

[43] Srinivas N, Jetter P, Ueberbacher BJ, et al. Peptidomimetic antibiotics target outer-membrane biogenesis in Pseudomonas aeruginosa. Science. 2010;327:1010-1013.

[44] Polyphor - POL7080. Available from: http://www.polyphor.com/products/pol7080. [Last accessed 13 November 2016]

[45] Polyphor- Ltd POL7080 - ClinicalTrials.gov. Available from: https://clinicaltrials.gov/ct2/show/NCT02897869. [Last accessed 13 November 2016].

[46] Afacan NJ, Yeung ATY, Pena OM, et al. Therapeutic potential of host defense peptides in antibiotic-resistant infections. Curr. Pharm. Des.. 2012;18:807-819.

[47] Dipexium Pharmaceuticals (DPRX) [Internet]. [cited 2016 Nov 13]. Available from: http://www.dipexiumpharmaceuticals.com/locilex/overview.

[48] Cutanea Life Sciences.. Available from: http://www.cutanea.com/.[Last accessed 13 November 2016].

[49] Soligenix- SGX942- Oral Mucositis -. Available from: http://www.soligenix.com/pipeline/biotherapeutics/sgx942-oral-mucositis/.[Last $\sim 28 \sim$ 
accessed 13 November 2016].

[50] Kudrimoti M, Curtis A, Azawi S, et al. Dusquetide: A novel innate defense regulator demonstrating a significant and consistent reduction in the duration of oral mucositis in preclinical data and a randomized, placebo-controlled phase $2 \mathrm{a}$ clinical study. J. Biotechnol. 2016;239:115-125.

[51] Lytix Biopharma - ltx109 . Available from: http://www.lytixbiopharma.com/antibacterials/ltx109/.[Last accessed 5 November 2016]

[52] Karolinska Development :: LL-37. Available from: http://www.karolinskadevelopment.com/en/portfolio/infections-and-woundhealing/11-37/.[Last accessed 13 November 2016]

[53] Cellceutix Corporation - Brilacidin. Available from: http://cellceutix.com/brilacidin/\#sthash.HimRvENG.dpbs. [Last accessed 22 November 2016]

[54] C3 Jian. Available from: http://www.c3-jian.com/c3-jian-completes-secondphase-2-clinical-trial-of-anti-cavity-drug/.[Last accessed 5 November 2016]

[55] Guo L, McLean JS, Yang Y, et al. Precision-guided antimicrobial peptide as a targeted modulator of human microbial ecology. Proc. Natl. Acad. Sci. U. S. A.. 2015;112:7569-7574.

* This study demonstrates the use of C16G2 (a targeted AMP that kills cariogenic pathogen Streptococcus mutans) to modulate the microbiome structure allowing insights into the key community role of specific bacterial species and also indicates the therapeutic potential of C16G2 to achieve a healthy oral microbiome.

[56] Helix BioMedix | Anti-Infective HB1345 Available from: http://www.helixbiomedix.com/antiinfective.html. [Last accessed 13 November 2016]

[57] Adenium Biotech. Available from: http://adeniumbiotech.com/pipeline/. [Last accessed 5 November 2016 ]. 
[58] Oragenics, Inc. (OGEN),OG253. Available from: http://www.oragenics.com/technology-pipeline/lantibiotics/og253. [Last accessed13 November 2016 ]

[59] Cantab Anti-infectives - Products Overview. Available from: http://www.cantabanti.com/nvb333.html. [Last accessed6 November 2016]

[60] Ni W, Shao X, Di X, et al. In vitro synergy of polymyxins with other antibiotics for Acinetobacter baumannii: a systematic review and meta-analysis. Int. J. Antimicrob. Agents . 2015;45:8-18.

**This meta-analisys estudied 70 articles and 31 conference proceedings reporting testing of polymyxins in combination with 11 classes consisting of 28 antibiotic types against 1484 A. baumannii strains

[61] Liu B, Liu Y, Di X, et al. Colistin and anti-Gram-positive bacterial agents against Acinetobacter baumannii. Rev. Soc. Bras. Med. Trop. 2014;47:451-456.

[62] Hornsey M, Wareham DW. In vivo efficacy of glycopeptide-colistin combination therapies in a Galleria mellonella model of Acinetobacter baumannii infection. Antimicrob. Agents Chemother. 2011;55:3534-3537.

[63] Yang H, Chen G, Hu L, et al. Enhanced efficacy of imipenem-colistin combination therapy against multiple-drug-resistant Enterobacter cloacae: in vitro activity and a Galleria mellonella model. J. Microbiol. Immunol. Infect. 2016; published on line 29 january 2106, doi:10.1016/j.jmii.2016.01.003

[64] D'Souza BB, Padmaraj SR, Rekha PD, et al. In vitro synergistic activity of colistin and ceftazidime or ciprofloxacin against multidrug-resistant clinical strains of Pseudomonas aeruginosa. Microb. Drug Resist. 2014;20:550-554.

[65] Leu H-S, Ye J-J, Lee M-H, et al. Synergy of imipenem/colistin methanesulfonate combinations against imipenem-nonsusceptible multidrug-resistant Acinetobacter baumannii. J. Microbiol. Immunol. Infect. 2014;47:406-411.

[66] Kumar SN, Lankalapalli RS, Kumar BSD. In vitro antibacterial screening of six proline-based cyclic dipeptides in combination with $\beta$-lactam antibiotics against medically important bacteria. Appl. Biochem. Biotechnol. 2014;173:116-128.

$$
\sim 30 \sim
$$


[67] Wang Z, Zhang L, Wang J, et al. Synergistic interaction of PMAP-36 and PRW4 with aminoglycoside antibiotics and their antibacterial mechanism. World J. Microbiol. Biotechnol. 2014;30:3121-3128.

[68] Giacometti A, Cirioni O, Kamysz W, et al. In vitro activity of MSI-78 alone and in combination with antibiotics against bacteria responsible for bloodstream infections in neutropenic patients. Int. J. Antimicrob. Agents . 2005;26:235-240.

[69] Simonetti O, Cirioni O, Ghiselli R, et al. In vitro activity and in vivo animal model efficacy of IB-367 alone and in combination with imipenem and colistin against Gram-negative bacteria. Peptides. 2014;55:17-22.

[70] Mulet-Powell N, Lacoste-Armynot AM, Viñas M, et al. Interactions between Pairs of Bacteriocins From Lactic Bacteria. Pharmaceuticals.2016;4:67

[71] Pletzer D, Hancock REW. Antibiofilm Peptides: Potential as Broad-Spectrum Agents. J. Bacteriol. 2016;198:2572-2578.

[72] Høiby N, Bjarnsholt T, Givskov M, et al. Antibiotic resistance of bacterial biofilms. Int. J. Antimicrob. Agents. 2010;35:322-332.

[73] Nuri R, Shprung T, Shai Y. Defensive remodeling: How bacterial surface properties and biofilm formation promote resistance to antimicrobial peptides. Biochim. Biophys. Acta. 2015;1848:3089-3100.

[74] Padhi A, Sengupta M, Sengupta S, et al. Antimicrobial peptides and proteins in mycobacterial therapy: current status and future prospects. Tuberculosis. 2014;94:363-373.

[75] Gutsmann T. Interaction between antimicrobial peptides and mycobacteria. Biochim. Biophys. Acta. 2016;1858:1034-1043.

[76] Silva T, Magalhães B, Maia S, et al. Killing of Mycobacterium avium by lactoferricin peptides: improved activity of arginine- and D-amino-acidcontaining molecules. Antimicrob. Agents Chemother. 2014;58:3461-3467.

[77] Rivas-Santiago B, Rivas Santiago CE, Castañeda-Delgado JE, et al. Activity of LL-37, CRAMP and antimicrobial peptide-derived compounds E2, E6 and CP26 against Mycobacterium tuberculosis. Int. J. Antimicrob. Agents. 2013;41:143- 
148.

[78] Lan Y, Lam JT, Siu GKH, et al. Cationic amphipathic D-enantiomeric antimicrobial peptides with in vitro and ex vivo activity against drug-resistant Mycobacterium tuberculosis. Tuberculosis. 2014;94:678-689.

[79] Ramón-García S, Mikut R, Ng C, et al. Targeting Mycobacterium tuberculosis and other microbial pathogens using improved synthetic antibacterial peptides. Antimicrob. Agents Chemother. 2013;57:2295-2303.

* The activity of a library of synthetic short peptides were tested against mycobacterial strains. Some of them presented a good activity, being some of the synthetic peptides a potential alternative for the antimycobacterial treatment.

[80] Rautenbach M, Troskie AM, Vosloo JA. Antifungal peptides: To be or not to be membrane active. Biochimie. 2016;130:132-145.

[81] NovaBiotics NP213.. Available from: http://www.novabiotics.co.uk/pipeline/novexatin-np213. [Last accessed 13 November 2016]

[82] Pacgen- Progress on PAC-113. Available from: http://www.marketwired.com/press-release/pacgen-announces-progress-on-pac113-license-2151000.htm. Last accessed 13 November 2016]

[83] Qi X, Zhou C, Li P, et al. Novel short antibacterial and antifungal peptides with low cytotoxicity: Efficacy and action mechanisms. Biochem. Biophys. Res. Commun. 2010. ;398(3):594-600

[84] Rivas L, Luque-Ortega JR, Andreu D. Amphibian antimicrobial peptides and Protozoa: Lessons from parasites. Biochim. Biophys. Acta - Biomembr. 2009;1788:1570-1581.

[85] Angélique L, Frederik W, Garmi J, et al. The Potential Use of Natural and Structural Analogues of Antimicrobial Peptides in the Fight against Neglected Tropical Diseases. Molecules. 2015;8: 15392-15433

[86] Gwadz RW, Kaslow D, Lee JY, et al. Effects of magainins and cecropins on the $\sim 32 \sim$ 
sporogonic development of malaria parasites in mosquitoes. Infect. Immun. 1989;57:2628-2633.

[87] Boman HG, Wade D, Boman IA, et al. Antibacterial and antimalarial properties of peptides that are cecropin-melittin hybrids. FEBS Lett. 1989;259:103-106.

[88] Feder R, Nehushtai R, Mor A. Affinity driven molecular transfer from erythrocyte membrane to target cells. Peptides. 2001;22:1683-1690.

[89] Vale N, Aguiar L, Gomes P. Antimicrobial peptides: A new class of antimalarial drugs? Front. Pharmacol. 2014;5:275.

[90] Zhou L-J, Xia J, Wei H-X, et al. Risk of drug resistance in Plasmodium falciparum malaria therapy - a systematic review and meta-analysis. Parasitol. Res. 2017;116:781-788.

[91] McGwire BS, Olson L, Tack BF, et al. Killing of African trypanosomes by antimicrobial peptides. J. Infect. Dis. 2003;188:146-152.

[92] Harrington JM. Antimicrobial peptide killing of African trypanosomes. Parasite Immunol. 2011. p. 461-469.

[93] Souza ALA, Faria RX, Calabrese KS, et al. Temporizin and temporizin-1 peptides as novel candidates for eliminating Trypanosoma cruzi. PLoS One. 2016;11:1-20.

[94] Lacerda AF, Pelegrini PB, De Oliveira DM, et al. Anti-parasitic peptides from arthropods and their application in drug therapy. Front. Microbiol. 2016;7:1-11.

[95] Torrent M, Pulido D, Rivas L, et al. Antimicrobial peptide action on parasites. Curr. Drug Targets. 2012;13:1138-1147.

[96] Landa A, Jiménez L, Willms K, et al. Antimicrobial peptides (Temporin A and Iseganan IB-367): Effect on the cysticerci of Taenia crassiceps. Mol. Biochem. Parasitol. 2009;164:126-130.

[97] Robinson MW, Donnelly S, Dalton JP. Helminth defence moleculesimmunomodulators designed by parasites! Front. Microbiol. 2013;4:1-4.

[98] Thivierge K, Cotton S, Schaefer DA, et al. Cathelicidin-like Helminth Defence $\sim 33 \sim$ 
Molecules (HDMs): Absence of Cytotoxic, Anti-microbial and Anti-protozoan Activities Imply a Specific Adaptation to Immune Modulation. PLoS Negl. Trop. Dis. 2013;7:e2307.

[99] Ageitos JM, Sánchez-Pérez A, Calo-Mata P, et al. Antimicrobial peptides (AMPs): Ancient compounds that represent novel weapons in the fight against bacteria. Biochem. Pharmacol. 2016 published on line 20 Setember 2016, DOI: 10.1016/j.bcp.2016.09.018

**This revision provides a comprensive revision of natural antimicrobial peptides, called defensins, in most living organisms

[100] Duquesne S, Destoumieux-Garzón D, Peduzzi J, et al. Microcins, gene-encoded antibacterial peptides from enterobacteria. Nat. Prod. Rep. 2007;24:708-734.

\section{LEGENDS TO FIGURES}

FIGURE 1. Chemical structures and sequences of cyclic antimicrobial peptides commercially available or in development (POL7080), as described in the text. 
FIGURE 2. Disclosed structures of linear antimicrobial peptides and peptidomimetics in development, as described in the text. Sequences are depicted in the single-letter code. $\mathrm{C}$ terminal amides are shown when available. 
Table 1. Temporal relationship between the antibiotic introduction in clinics and time of resistance development

\begin{tabular}{|c|c|c|}
\hline Antibiotic deployment & YEARS & Antbiotic resistance observed \\
\hline sulfonamides & Before-1935 & \\
\hline & $1936-1940$ & \\
\hline $\begin{array}{l}\text { B-lactams (penicillin) } \\
\text { Streptomycin }\end{array}$ & 1941-1945 & sulfonamides \\
\hline $\begin{array}{c}\text { Chloramphenicol } \\
\text { Tetracyclines } \\
\text { colistin }\end{array}$ & $1946-1950$ & B-lactams (penicillin) \\
\hline Macrolides (Erythromycin) & $1951-1955$ & Tetracyclines \\
\hline $\begin{array}{l}\text { Glycopeptides } \\
\text { (Vancomycin) }\end{array}$ & $1956-1960$ & $\begin{array}{c}\text { Streptomycin } \\
\text { Chloramphenicol } \\
\text { colistin }\end{array}$ \\
\hline \multirow[t]{7}{*}{$\begin{array}{c}\text { Cephalosporins } \\
\text { Quinolones (nalidixic acid) }\end{array}$} & $1961-1965$ & \\
\hline & $1966-1970$ & $\begin{array}{c}\text { Cephalosporins } \\
\text { Quinolones (nalidixic acid) }\end{array}$ \\
\hline & $1971-1975$ & \\
\hline & 1976-1980 & \\
\hline & $1981-1985$ & \\
\hline & 1986-1990 & $\begin{array}{l}\text { Macrolides (Erythromycin) } \\
\text { Glycopeptides (Vancomycin) }\end{array}$ \\
\hline & $1991-1995$ & \\
\hline \multirow{3}{*}{ Oxazolidinones (linezolid) } & $1996-2000$ & \\
\hline & $2001-2005$ & Oxazolidinones (linezolid) \\
\hline & $2006-2010$ & Oxazolidinones (linezolid) \\
\hline $\begin{array}{l}\text { ¿new antimicrobial } \\
\text { peptides? }\end{array}$ & 2011-beyond & ???? \\
\hline
\end{tabular}

URL: http://mc.manuscriptcentral.com/eobt Email: David.Grech@informa.com 
Table 2: Selection, main properties and stage of development of pipeline AMPs.

Chemical structures and peptide sequences may be found in figures 1 and 2

\begin{tabular}{|c|c|c|c|c|c|}
\hline $\begin{array}{l}\text { Compound } \\
\text { name }\end{array}$ & Origin & $\begin{array}{l}\text { Mechanism } \\
\text { of Action }\end{array}$ & Indications & $\begin{array}{l}\text { Development } \\
\text { stage }\end{array}$ & $\begin{array}{l}\text { Company } \\
\text { (reference) }\end{array}$ \\
\hline Surotomycin & Daptomycin & $\begin{array}{c}\text { Membrane } \\
\text { disruptor, } \\
\text { depolarization } \\
\end{array}$ & $\begin{array}{l}\text { C.difficile- } \\
\text { associated } \\
\text { diarrhea } \\
\end{array}$ & Phase III & $\begin{array}{l}\text { Merck-Cubist } \\
(41)\end{array}$ \\
\hline POL7080 & protegrin I & LptD binding & $\begin{array}{c}\text { VABP, } \\
\text { bronchiectasis }\end{array}$ & Phase II & $\begin{array}{l}\text { Polyphor } \\
(44,45)\end{array}$ \\
\hline $\begin{array}{l}\text { Pexiganan } \\
\text { (Locilex), } \\
\text { MSI } 80 \\
\end{array}$ & Magainin derivative & $\begin{array}{l}\text { Disruption of } \\
\text { bacterial cell } \\
\text { membrane }\end{array}$ & $\begin{array}{l}\text { skin and skin } \\
\text { structure } \\
\text { infections } \\
\end{array}$ & $\begin{array}{l}\text { Evaluating } \\
\text { development }\end{array}$ & $\begin{array}{c}\text { Dipexium } \\
\text { Pharmaceuticals } \\
(47) \\
\end{array}$ \\
\hline $\begin{array}{l}\text { Omiganan } \\
\text { (CLS001) }\end{array}$ & Indolicin & $\begin{array}{l}\text { Cytoplasmatic } \\
\text { membrane } \\
\text { depolarization }\end{array}$ & $\begin{array}{c}\text { Rosacea, } \\
\text { Acne, atopic } \\
\text { dermatitis, } \\
\text { vulvar } \\
\text { intraepithelial } \\
\text { neoplasia }\end{array}$ & $\begin{array}{l}\text { Phase III } \\
\text { Phase II }\end{array}$ & $\begin{array}{l}\text { Cutanea Life } \\
\text { Sciences } \\
(48)\end{array}$ \\
\hline SGX 942 & Synthetic & $\begin{array}{l}\text { Innate defense } \\
\text { regulator }\end{array}$ & $\begin{array}{c}\text { Oral mucositis } \\
\text { in head and neck } \\
\text { cancer }\end{array}$ & Phase II & $\begin{array}{c}\text { Soligenix } \\
\text { (49) }\end{array}$ \\
\hline $\begin{array}{l}\text { LTX-109 } \\
\text { (Lytixar) }\end{array}$ & $\begin{array}{c}\text { Synthetic } \\
\text { peptidomimetic }\end{array}$ & $\begin{array}{l}\text { Membrane } \\
\text { disruptor } \\
\text { (cell lysis) }\end{array}$ & $\begin{array}{l}\text { Diabetic foot } \\
\text { and skin } \\
\text { infections } \\
\text { impetigo }\end{array}$ & Phase I/II & $\begin{array}{l}\text { Lytix Biopharma } \\
\text { (51) }\end{array}$ \\
\hline Brilacidin & $\begin{array}{l}\text { Synthetic defensin } \\
\text { arylamide } \\
\text { peptidomimetic }\end{array}$ & $\begin{array}{c}\text { Bacterial cell } \\
\text { membrane } \\
\text { disruptor }\end{array}$ & $\begin{array}{c}\text { ABSSSI } \\
\text { Infections, } \\
\text { Oral mucositis }\end{array}$ & $\begin{array}{l}\text { Phase III } \\
\text { Phase II }\end{array}$ & $\begin{array}{l}\text { Cellceutix } \\
\text { (53) }\end{array}$ \\
\hline C16G2 & $\begin{array}{c}\text { Hybrid }(\mathrm{G} 2+S . \text { mutans } \\
\text { region })\end{array}$ & $\begin{array}{l}\text { Membrane } \\
\text { disruptor }\end{array}$ & $\begin{array}{l}\text { Dental caries, } \\
\text { anti-cavity }\end{array}$ & Phase II & $\begin{array}{l}\text { C3 Jian } \\
(54)\end{array}$ \\
\hline HB1345 & Synthetic lipopeptide & $\begin{array}{l}\text { lipoteichoic } \\
\text { acid binding, } \\
\text { presumably } \\
\text { membrane } \\
\text { disruptor }\end{array}$ & $\begin{array}{l}\text { Skin infections, } \\
\text { acne }\end{array}$ & Preclinical & $\begin{array}{l}\text { Helix BioMedix } \\
\text { (56) }\end{array}$ \\
\hline AA-139 & Arenicin & $\begin{array}{l}\text { membrane } \\
\text { disruptor }\end{array}$ & $\begin{array}{l}\text { MDR cUTI, } \\
\text { pneumonia }\end{array}$ & Preclinical & $\begin{array}{l}\text { Adenium Biotech } \\
\text { (57) }\end{array}$ \\
\hline $\begin{array}{l}\text { OG253 and } \\
\text { OG716 }\end{array}$ & Lantibiotics & $\begin{array}{l}\text { Possibly by } \\
\text { Inhibition of } \\
\text { cell wall } \\
\text { biosynthesis, } \\
\text { pore formation }\end{array}$ & $\begin{array}{l}\text { Clostridium } \\
\text { difficile } \\
\text { infection in } \\
\text { enteritis. }\end{array}$ & $\begin{array}{c}\text { Pre- } \\
\text { Investigational } \\
\text { New Drug } \\
\text { (pre-IND) }\end{array}$ & $\begin{array}{l}\text { Oragenics } \\
\qquad(58)\end{array}$ \\
\hline NVB333 & $\begin{array}{c}\text { Semisynthetic } \\
\text { derivative of } \\
\text { deoxyactagardine } \\
\text { B (lantibiotic) }\end{array}$ & $\begin{array}{l}\text { Inhibition of } \\
\text { cell wall } \\
\text { biosynthesis }\end{array}$ & $\begin{array}{l}\text { Gram-positive } \\
\text { caused } \\
\text { infections }\end{array}$ & $\begin{array}{l}\text { Drug candidate, } \\
\text { preclinical }\end{array}$ & $\begin{array}{l}\text { Cantab Anti- } \\
\text { infectives } \\
(59)\end{array}$ \\
\hline $\begin{array}{c}\text { NP213 } \\
\text { (Novexatin) }\end{array}$ & $\begin{array}{c}\text { Cyclic arginine-based } \\
\text { heptamer }\end{array}$ & $\begin{array}{c}\text { Membrane } \\
\text { disruption }\end{array}$ & $\begin{array}{c}\text { Antifungal, } \\
\text { onychomycosis }\end{array}$ & Phase IIa & $\begin{array}{c}\text { NovaBiotics } \\
(81)\end{array}$ \\
\hline $\begin{array}{c}\text { NP339 } \\
\text { (Novamycin) }\end{array}$ & $\begin{array}{l}\text { poly-Arginine based } \\
\text { cationic peptide }\end{array}$ & $\begin{array}{l}\text { Membrane } \\
\text { perturbation }\end{array}$ & $\begin{array}{l}\text { Yeast, mould } \\
\text { infections }\end{array}$ & preclinical & $\begin{array}{c}\text { NovaBiotics } \\
(81)\end{array}$ \\
\hline P113 & Histatin 5 & $\begin{array}{c}\text { Possible } \\
\text { surface-active } \\
\text { agents, induce } \\
\text { ATP release, } \\
\text { activity on } \\
\text { mitochondria }\end{array}$ & $\begin{array}{l}\text { Gengivitis, oral } \\
\text { candidasis }\end{array}$ & Phase II & $\begin{array}{l}\text { Pacgen } \\
(82)\end{array}$ \\
\hline
\end{tabular}




\section{Figure 1}

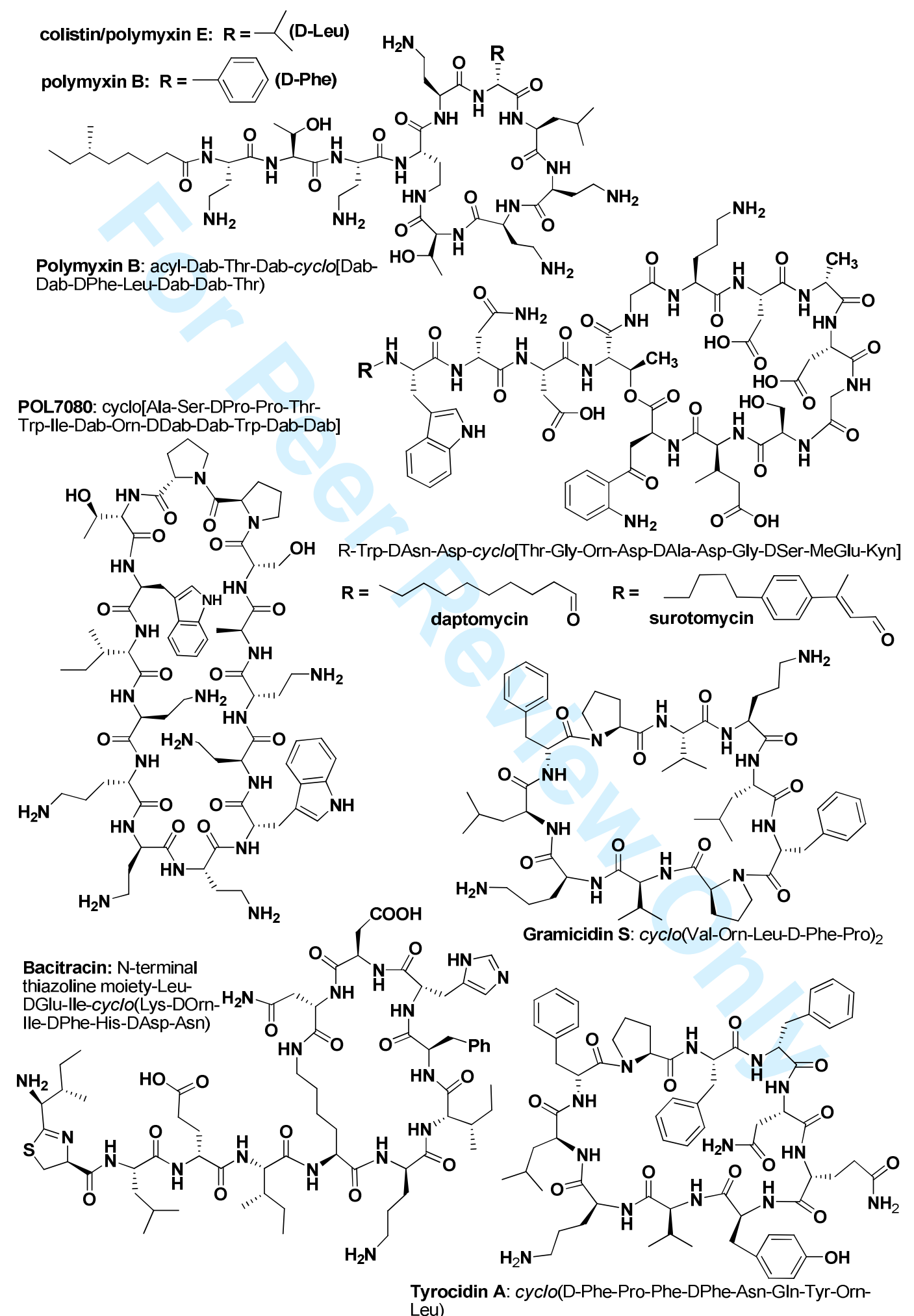

URL: http://mc.manuscriptcentral.com/eobt Email: David.Grech@informa.com 
1

2

3

4

5

6

7

8

9

10

11

12

13

14

15

16

17

18

19

20

21

22

23

24

25

26

27

28

29

30

31

32

33

34

35

36

37

38

39

40

41

42

43

44

45

46

47

48

49

50

51

52

53

54

55

56

57

58

59

60

Figure 2:<smiles>CC(C)(C)c1cc(C(C)(C)C)c2[nH]c(C(C)(C)C)c(CC(NC(=O)C(N)CCCNC(=N)N)C(=O)NC(CCCNC(=N)N)C(=O)NCCc3ccccc3)c2c1</smiles><smiles>N=C(N)NCCCCC(=O)Nc1cc(C(F)(F)F)cc(NC(=O)c2cc(C(=O)Nc3cc(C(F)(F)F)cc(NC(=O)CCCCNC(=N)N)c3OC3CCNC3)ncn2)c1OC1CCNC1</smiles>

C16G2:TFFRLFNRSFTQALGKGGG KNLRIIRKGIHIIKKY-amide

SGX942: RIVPA-amide

Pexiganan: GIGKFLKKAKKFGKAFVKILKK-amide

Omiganan: ILRWPWWPWRRK-amide

LL-37: LLGDFFRKSKEKIGKEFK RIVQRIKDFLRNLVPRTES

P-113: AKRHHGYKRKFH-amide

HB1345: decanoyl KFKWPW-amide

AA139: GFCWYVCARRNGARVCYRRCN, (disulfide bridges between C2-C2O; C7-C16)

DPK-060: GKHKNKGKKNGKHNGWKWWW 
Article highlights

- Antimicrobial peptides, potentially, offer advantages to become useful antimicrobials as they are less prone to generate microbial resistance.

- There are circa of 20 new antimicrobial peptides in diferent stages of development.

- Natural antimicrobial peptides could be a starting point for the research on antimicrobial peptides.

- Due to the main mechanism of action antimicrobial peptides could be a useful hope when used in combination with classical antibiotics.

- Peptides with anti-mycobacterial, anti-fungal and anti-parasitic activities constitute also a promising family of compounds. 